\title{
跨座型モノレールの鋼製軌道析の横析連結部の疲労試験 \\ FATIGUE TEST OF CROSS BEAM CONNECTIONS IN STEEL TRACK GIRDERS FOR STRADDLE-TYPE MONORAIL
}

\author{
前田幸雄*・福岡哲二**・大倉一郎***・磯崎弘治**** \\ By Yukio MAEDA, Tetsuji FUKUOKA, Ichiro OKURA and Kohji ISOZAKI
}

\begin{abstract}
A steel elevated guideway for a straddle-type monorail consists of two main track girders and several I-shaped cross beams which connect the two girders. The connection of a cross beam to the track girder is subjected to bending moment, and a number of cycles of the moment reaches a total of 2.8 millions for 70 years.

To study on the fatigue strength of the connection, fatigue tests with three-type connection models have been carried out.

The present paper reports the fatigue test results and discusses characteristics of the fatigue strength of three-type connections.

Keywords : monorail, steel girder, cross beam connection, fatigue
\end{abstract}

\section{1. 序論}

現在, 大阪モノレールが大阪国際空港から阪急南茨木 駅までの $13.7 \mathrm{~km}$ の区間で建設されている. 大阪モノ レールは跨座形式である. 標準的な軌道桁としては, 支 間が $22 \mathrm{~m}$ の PC 桁が使用されている. しかし, 既設道 路との交差部, 河川横断部, 複雑な曲線部では鋼製軌道 析が使用されている.鋼製軌道析の一例を Fig. 1 に示す. 並列の軌道桁が I 断面の横桁で連結されている. 軌道桁 の幅はモノレール車両の建築限界の制限を受けるために $585 \mathrm{~mm}$ から $660 \mathrm{~mm}$ で, 高さは軌道桁の支間に応じて 約 $2.2 \mathrm{~m}$ から約 $3.3 \mathrm{~m}$ まである. 鋼製軌道枌の上フラ ンジの上をモノレール車両が走行する.

鋼製軌道析はモノレール車両の走行による繰返し荷重 を受けるために, 疲労に対する安全性を確保しなければ ならない. 建設予定の鋼製軌道析の疲労設計を検討した 結果, 次の理由から, 軌道桁之横枌の連結部には疲労亀

* 正会員 工博 近畿大学教授 理工学部土木工学科 ( ( 577 東大阪市小若江 3-4-1)

** 正会員 工修 (株)三井造船昭島研究所 (テ196 昭島市つつじが丘 1-1-50)

*** 正会員 工博 大阪大学助手 工学部土木工学科 ( 5565 吹田市山田丘 2-1)

**** 正会員 工修 大阪府北部特定事業建設事務所 ( 5567 茨木市西駅前町 5-10)
裂が発生する可能性があると予想した。

a) 軌道桁と横桁は格子構造を形成する.したがって, 横枌が荷重分配を行うために, 軌道析と横桁の連結部に は曲げモーメントとせん断力が生じる. 次章で述べるよ うに，2つの軌道析をモノレール車両が交互に通過する と, 横桁連結部には交番応力が生じる.

b) Fig. 1 の横断面図からわかるように, 軌道桁と横 析は L 型を形成する. L 型の隅角部すなわち軌道析と 横枌の連結部には構造的な応力集中が生じる.

c）横析と軌道桁の連結部では, 軌道析のウェブ, ダ イアフラム, リブプレート, 横桁の上フランジとウェブ などの各鋼板が交差し, 溶接が集中している.

跨座型モノレールの鋼製軌道析の横析連結部の疲労強 度特性を明らかにし, 適切な構造を設計するために, 横 桁連結部の疲労試験を実施した. その結果, 同連結部は 疲労を受けやすい構造であることが判明した. 本論文で は,この疲労試験において観察された横析連結部の疲労 強度特性と構造の改良法について報告する.

\section{2. 鋼製軌道桁の横桁連結部の疲労試験}

\section{（1）疲労試験の対象となった軌道桁}

建設予定の 18 の鋼製軌道析の計算書によると, 支間 が比較的短い軌道桁の横析に大きな曲げ応力が生じる傾 


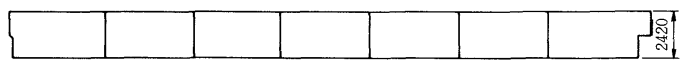

(a) Side View

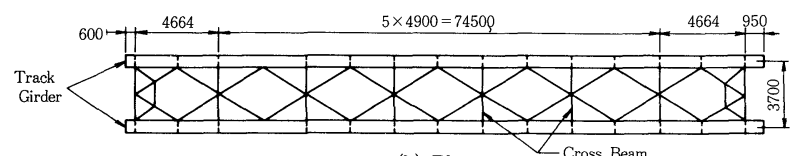

(b) Plan

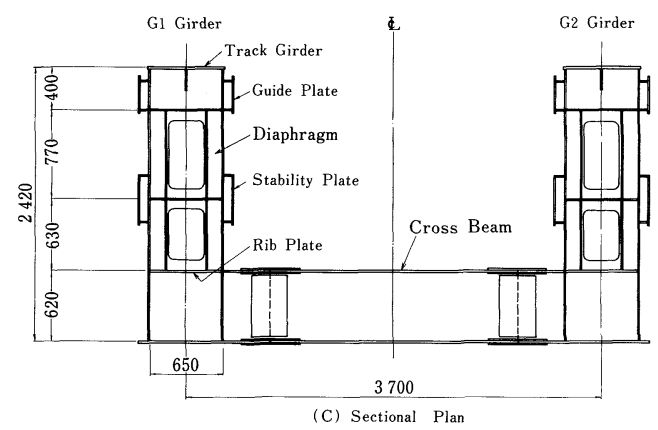

Fig. 1 General View of Steel Track Girder for Monorail.

向があった．そこで，横桁の曲げ応力が大きい方から 3 つの鋼製軌道桁を選び，格子桁計算を行った。モノレー ル車両荷重はFig. 2 に示す移動連行荷重で一軸当たりの 重量は, 満載時で $108 \mathrm{kN}$, 平均荷重時で $88.2 \mathrm{kN}$, 空 車時で $78.4 \mathrm{kN}$ である. 疲労設計のための活荷重は, 平均荷重に衝撃係数 1.298 をかけた $114 \mathrm{kN}$ とする ${ }^{1)}$.

横枌に生じる曲げモーメントの分布とせん断力の分布 を模式的にFig. 3 に示す. Fig. 3 (A) に示すように, 荷重が軌道桁 G 1 に載荷された場合, 曲げモーメント は横桁の中央で 0 になり, 軌道桁 G 1 の位置の曲げモー メントと大きさが同じで，これと符号が反対の曲げモー

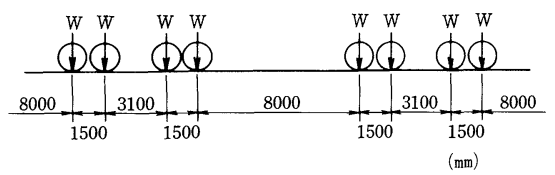

Fig. 2 Loading Pattern of Monorail.

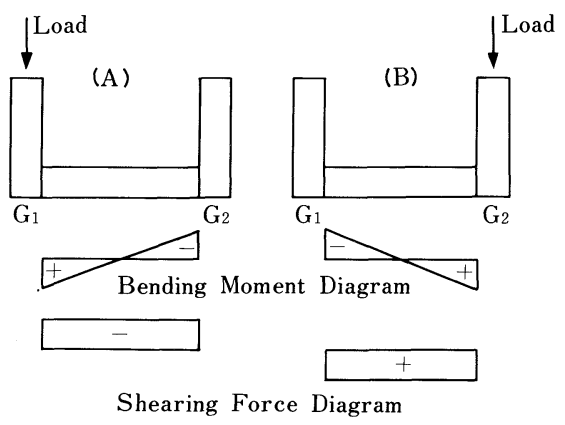

Fig. 3 Forces Acting on Cross Beam.
メントが軌道桁 G 2 の位置に生じる. 他方, Fig. 3(B) に示すように，荷重が軌道析 G 2 に載荷された場合の 曲げモーメントの分布とせん断力の分布は, それぞれ Fig. 3(A) の分布と符号が反対の分布になる。したがつ て，モノレールが軌道桁 G 1 と G 2 を交互に通過した 場合，軌道桁と横桁の連結部には大きさの等しい交番応 力が生じる.

格子析解析の結果, Fig. 1 に示した寸法の鋼製軌道析 の横析の曲げ応力が最も大きかったので，この軌道桁の 横析連結部を疲労試験の対象とした. 軌道桁と横桁の連 結部の詳細を Fig. 4 に示す. 横析の下フランジは軌道析 の下フランジと一体となっており, 両フランジの結合部 には応力集中を緩和するために半径 $200 \mathrm{~mm}$ のフィレッ トが設けてある. 横桁の上フランジと軌道桁のウェブの 交差部における横栴の上フランジの端部形状は軌道析応 力に対する国鉄建造物設計標準 ${ }^{21}$ に従っている. 軌道析 の内側には, 横桁の上フランジと同じ高さにリブプレー トを設けている. 軌道桁内のダイアフラムには施工上の

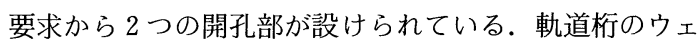
ブと横析の上フランジおよび軌道桁内のリブプレートと の溶接は, $\mathrm{K}$ 型開先の完全溶け込み溶接である.

\section{(2) 疲労試験体}

軌道析と横析の連結部の応力性状を明らかにするため に, Fig. 5 に示すような軌道桁と横桁から成るモデルの 有限要素法解析を行った。横枌連結部から $1225 \mathrm{~mm} の$ 等距離にある垂直補剛材の位置までの G 1 軌道析の部 分亡, 軌道桁 $\mathrm{G} 2$ の内側のウェブの位置までの横析の 部分をモデル化した. 境界条件としては, 軌道桁の両端 


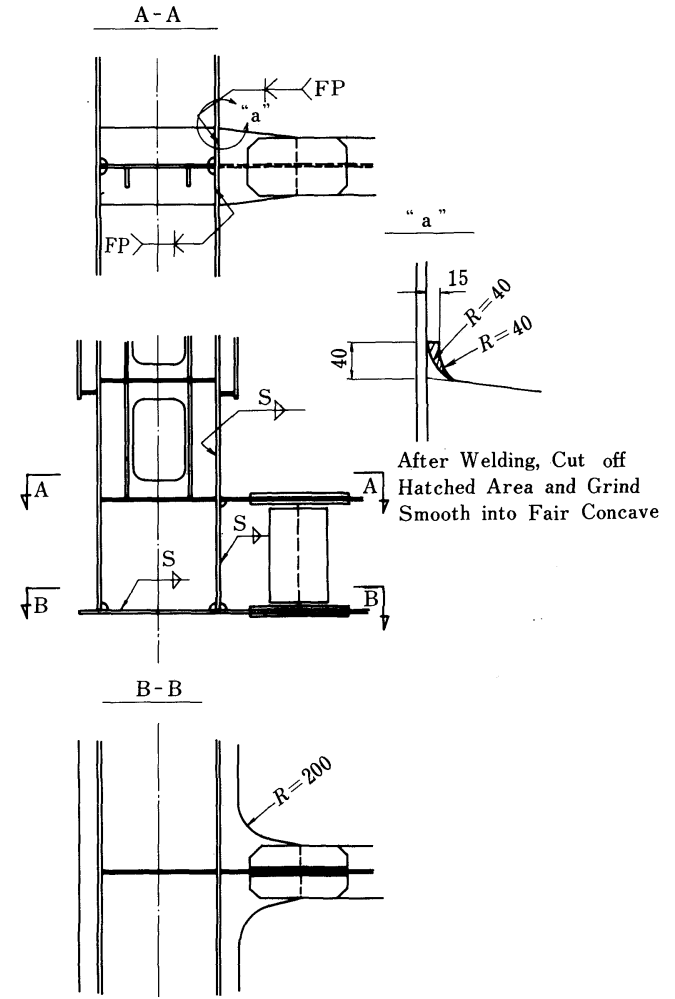

Fig. 4 Connection Details of Cross Beam to Main Track Girder.

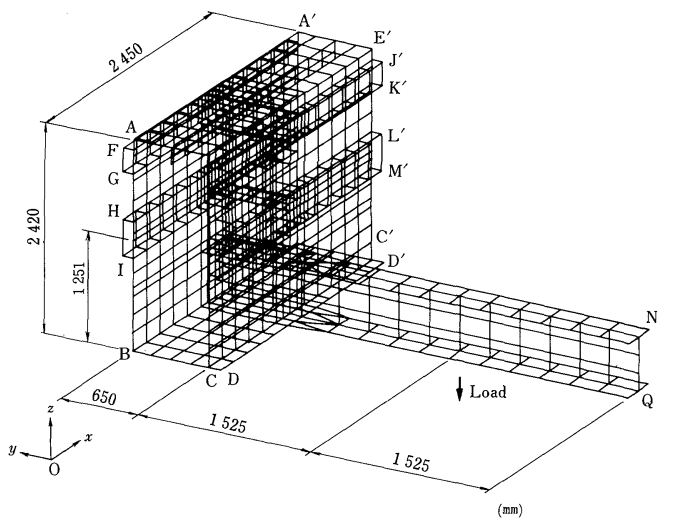

Fig. 5 Model for FEM Analysis.

で $y$ - $z$ 面内の変位を拘束し, さらに軌道桁下フランジ の両端で $x$ 方向の変位を拘束している. 横桁の先端は 自由端とした.前述したように, 横析の中央では曲げモ一 メントが0になり, せん断力のみ生じるので横析の中央 に $P=9.81 \mathrm{kN}$ の集中荷重を載荷した. この解析モデル をA-1 モデルとよぶ.さらに, Fig. 5 の軌道桁の両端の 断面上の節点の変位を自由にし, 軌道析の安定面板が存 在する平面 $z=1251 \mathrm{~mm}$ 上の節点の変位をすべて拘束

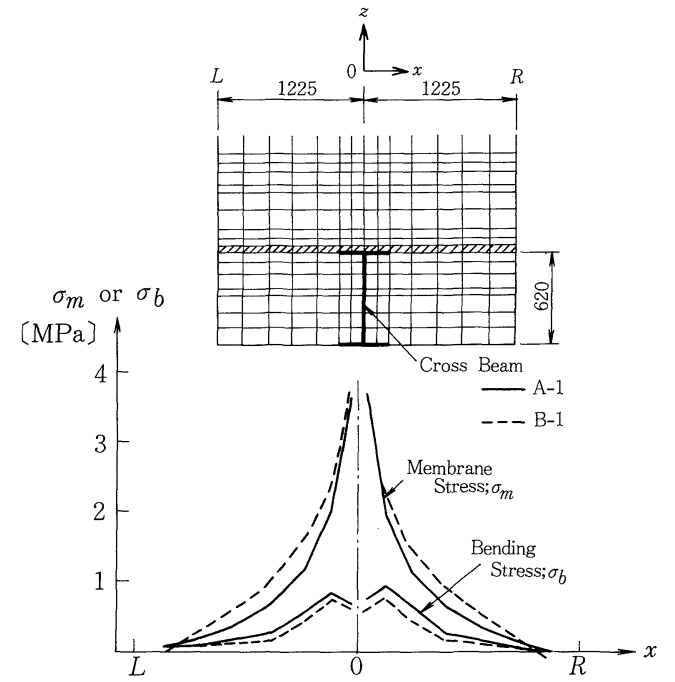

Fig. 6 Stresses in the Vertical Direction on Track Girder Web.

したモデルについても解析を行った. この解析モデルを B-1 モデルとよぶ. A-1 モデルは実橋の横桁連結部に 生じる応力を調べるためのモデルであり, B-1 モデル は疲労試験体の規模を決めるためのモデルである．使用 した有限要素は面内変位成分と面外変位成分からなる 1 節点が 6 自由度をもつ三角形および四角形要素である ${ }^{3)}$.

計算の結果得られた軌道桁ウェブに生じる鉛直方向の 膜応力と板曲げ応力の分布を Fig. 6 に示す. A-1 モデル と B-1 モデルの膜応力と板曲げ応力は, それぞれ互い に近い值を示している. また，横枌上フランジにおける 值も後に Table 1 に示すように両モデルでほとんど差が ない. したがって，B-1 モデルに従って試験体を製作 してよいと考えた.

疲労試験体を Fig. 7 に示す. 疲労試験体の軌道析の高 さは実際の軌道析の安定面板の中央の位置まで考慮さ れ, 上端に厚さ $30 \mathrm{~mm}$ の補強板が取り付けてある.

Fig. 6 に示したように，B-1 モデルにおいて軌道析ウェ ブの両端に流れる応力は小さく, 試験体における軌道析 の長さは解析モデルより短くしても影響はないと考え, $1400 \mathrm{~mm}$ とした. 横桁の長さは実橋の横桁の支間長の 半分とした。使用した鋼材はSM 41 B である. Fig. 7 に示した横枌の連結構造をストレート構造 $(\mathrm{ST})$ とよぶ.

\section{（3）疲労試験の結果}

疲労試験は電気油圧式 $50 \mathrm{t}$ 疲労試験機で行った. 試 験状況を Fig. 8 とPhoto 1 に示す. 試験体を反転し, 軌 道析の上端の補強板をボルトで試験ベッドに固定した. 横桁の端部にユニバーサルジョイントを取り付け，これ を介して繰返し荷重を与えた.

荷重の大きさが $147 \mathrm{kN}$ の両振りの荷重制御で疲労 

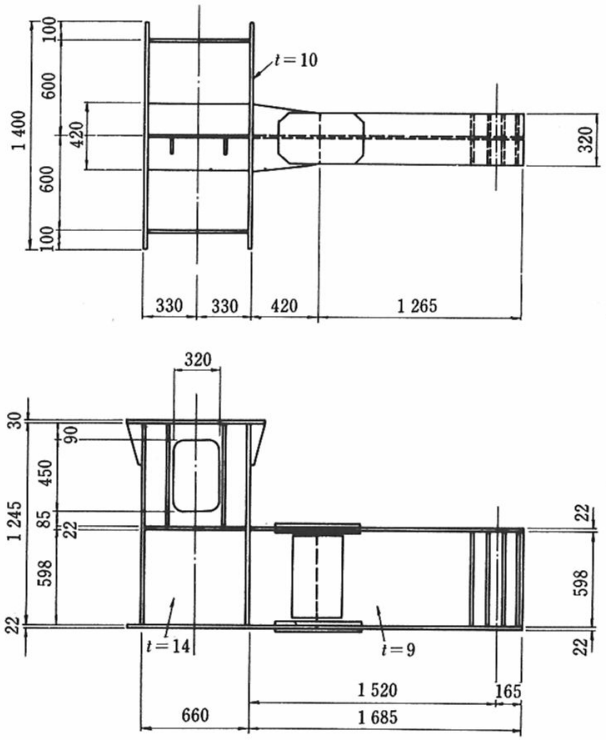

Fig. 7 Test Model of Straight Type (ST).
(1) Pulsator
(2) Load Cell
(3) Spacer
(4) Universal Joint
(5) Test Model
(6) $\mathrm{Ber}^{\mathrm{r}}$

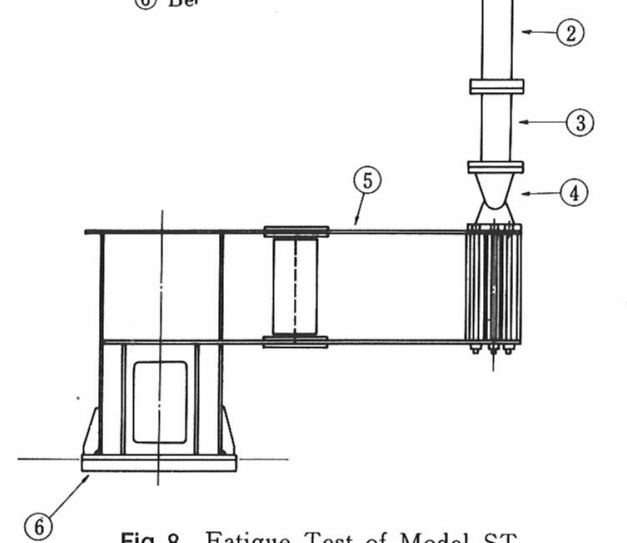

Fig. 8 Fatigue Test of Model ST.

武験を行った。その結果, 繰返し数 5700 回で軌道枌の ウェブと横桁の上フランジとの溶接部のウェブ側の止端 に最初の亀裂が発見された。その後 21.9 万回まで試験 を続行し載荷部の変位が大きくなったので試験を終了し た. 試験終了後の亀裂の状況を Fig. 9 に示す. 最初に発 見されたのは亀裂（a）で，発見時 $45 \mathrm{~mm}$ の表面亀裂で あったが，その後軌道桁ウェブを貫通し Fig. 9 の亀裂 (c)，(b)，(d) のようにダイアフラムとウェブの隅肉

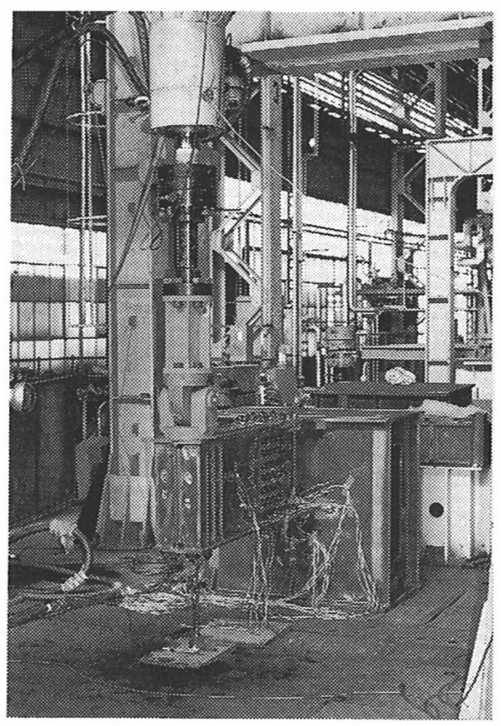

Photo 1 Overall View of Test Setup.
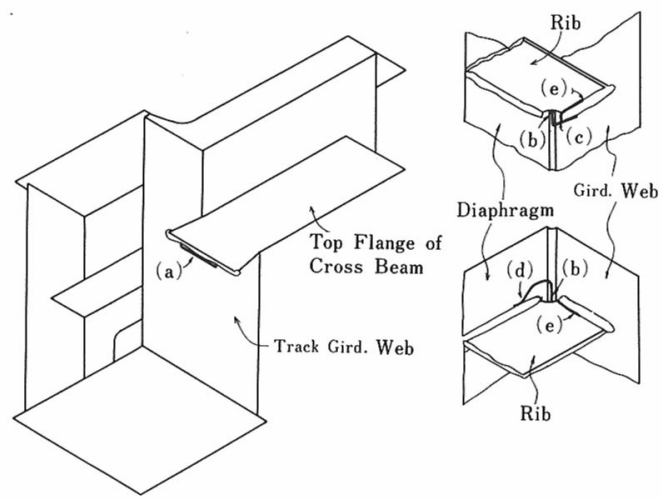

Fig. 9 Fatigue Cracks in Test Model ST.

溶接部を経て，ダイアフラムへ進展している.ダイアフ ラムに亀裂が伝播したときの繰返し数は 4 万回である。 亀裂 (e) は軌道桁内のリブプレートのスカラップから 発生した亀裂で, リブプレート側の溶接止端に沿ってリ ブプレートの全幅にわたって進展している．この亀裂は 試験終了後発見されたもので, その発生時期は不明であ る.この亀裂 (e) によってリブプレートが破断され, 横栴の上フランジから軌道桁に流れる力が遮断されたこ とが横桁のたわみを大きくした原因である.

疲労試験の対象亡なった鋼製軌道桁においては, 疲労 設計荷重に対して生じる横桁のせん断力は，格子計算に よると $\pm 73.9 \mathrm{kN}$ で，その繰返し数は 70 年間で 281 万 回となる.この条件を上回る疲労強度を有するためには, $\pm 147 \mathrm{kN}$ の荷重に対して,$S-N$ 線図の勾配を-1/4 $-1 / 3$ と仮定すると， 18 万～ 35 万回以上の繰返しに耐 える必要がある，ところが, 本構造の実験結果では，そ 
れよりもはるかに少ない5700回で疲労亀裂が発生し た. したがって，構造の改良が必要と考える.

\section{3. 軌道桁と横桁の連結部の構造改良}

横析の上フランジと軌道桁のウェブの交差部の構造改

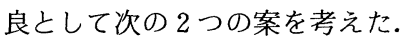

a）横桁の上フランジと軌道析のウェブの交差部に， コーナープレートを設ける．コーナープレートの大きさ は建築限界の制限を受け，Fig. 10 に示す形状・寸法之 なる。

b）横桁の端部に Fig. 11 に示すようなテーパーを付 ける.ただし，この場合，軌道析内のダイアフラムの施 工用の孔を下側に移す必要が生じる.テーパーの大きさ は建築限界の制限を受ける。

a) と b) の構造改良の効果を知るために, Table 1 に 示す各構造について Fig. 5 と同様のモデルによる有限要 素法解析を行った. Table 1 で黒く塗られた四角形は, ダイアフラムと同厚の添接板で，ダイアフラムに開けら れた孔を製作後塞ぐことを表わしている．コーナープ レートの板厚は，軌道桁内のダイアフラムあるいは横桁 の上フランジの厚さに対応させて，14 $\mathrm{mm}$ と $22 \mathrm{~mm}$ の $2 つ$ つースの場合について検討した. A シリーズと $\mathrm{C}$ シリーズは軌道析の両端に境界条件を与える, 実際 の軌道桁を想定したモデルであり， B シリーズと D シ リーズは軌道桁の安定面板の中央 $(z=1251 \mathrm{~mm})$ の位 置の節点の変位を拘束する, 疲労試験体を想定したモデ ルである. 解析モデル A-1 と B-1 は2.（2）で述べた モデルと同じである．表中の数值は，横桁の中央に集中
荷重 $P=9.81 \mathrm{kN}$ を載荷したときの, 軌道桁ウェブと横 桁上フランジの交差部に生じる膜応力と板曲げ応力の值 である.コーナープレートを設けた構造では，コーナー プレートの上端の軌道桁ウェブとコーナープレート上端 に生じる応力值を Table 1 に示してある.

A シリーズの解析結果から次のことがいえる.

1）コーナープレートを設けると，横桁上フランジと 軌道桁ウェブの交差部に生じる応力は著しく減少する.

2）コーナープレートの上端の軌道桁ウェブとコー ナープレート上端に大きな応力が生じる.

3）コーナープレートの上端の軌道桁のウェブの応力 は, 軌道桁内のダイアフラムの下の孔を塞ぐと幾分減少 する.

4） $22 \mathrm{~mm}$ の板厚のコーナープレートに生じる応力 が $14 \mathrm{~mm}$ の板厚のコーナープレートに生じる応力より 小さい.

これらの特性から，添接板でダイアフラムの下の孔を 塞ぎ, Fig. 10 に示すような $22 \mathrm{~mm}$ の板厚のコーナープ レートを横桁の上フランジと軌道桁のウェブの間に設け ることを，横桁連結部の改良構造として採用した。この 横枌の連結構造をコーナープレート付構造 (CP) とよ s..

他方, 解析モデル A-1 と C シリーズの比較により, 横析の端部にテーパーを付けることに関して次のことが わかった。

1) 軌道桁のウェブと横桁の上フランジに生じる応力 が減少する.

2）ダイアフラムの下の製作用の孔を塞ぐと，交差部

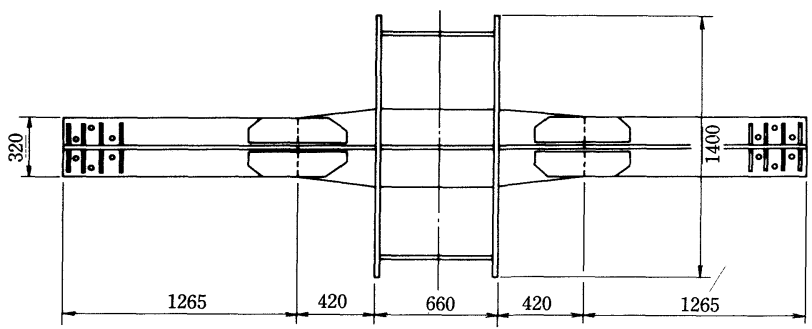

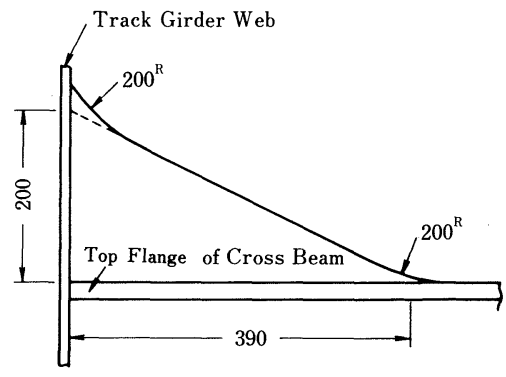

Fig. 10 Shape of Corner Plate.

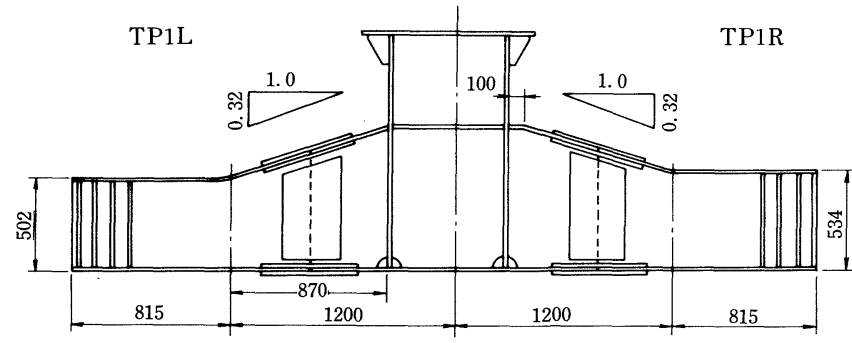

Fig. 11 Test Model of Taper Type (TP) TP1R TP1L. 


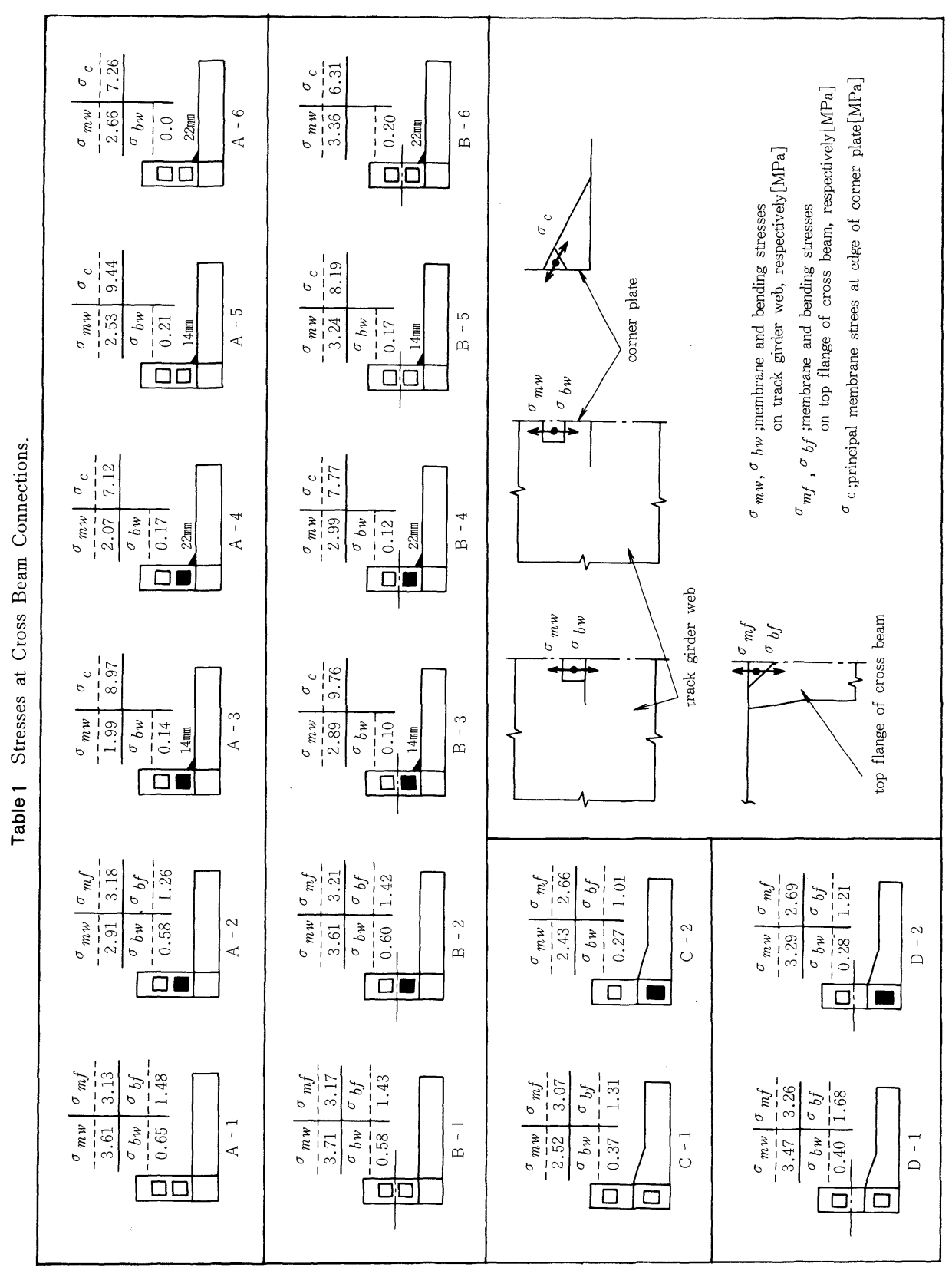


に生じる応力が減少する.

これらの特性から，ダイアフラムの下の製作用の孔を 塞ぎ，Fig. 11 に示すようなテーパーを有する横桁を， 横桁連結部の構造改良として取り上げた.この構造の連 結構造をテーパー構造 (TP) とよぶ.

コーナープレート付構造の実橋モデル A-4 とこれに 対応する試験モデル B-4 との比較，あるいは，テーパー 構造の実橋モデル C-2 とこれに対応する試験モデル D-2 との比較からわかるように，いずれも試験モデル の交差部に生じる応力が実橋モデルの応力よりも大きく なっている. したがって，試験モデル B-4，D-2 に基 づいて行われた疲労試験は, 実橋よりも厳しい条件下で 行われることになり，そこで得られた結果は安全側の結 果となると考える.

\section{4. コーナープレート付構造 (CP) の疲労試 験}

試験体は 2 体作製し疲労試験を実施した．試験体の構 造は Fig. 6 の ST 構造の軌道桁ウェブと横桁フランジの 交差部に Fig. 11 のコーナープレートを付けたもので, コーナープレートの端部はグラインダーで滑らかに仕上 げた．ST 構造の疲労試験では, 軌道桁内のリブプレ一 トのスカラップから疲労亀裂が発生し，リブプレートが 破断した.そこで, $\mathrm{CP}$ 構造ではリブプレートのスカラッ プを埋め戻した．さらに，ダイアフラムの孔を添接板で

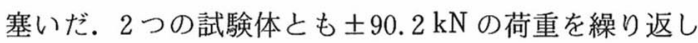
た. 1 体目の試験 $(\mathrm{CP}-1)$ では, 繰返し数 230 万回でコー ナープレート端部の回し溶接部に疲労亀裂が生じた. 270 万回で軌道桁ウェブを貫通し，軌道桁内側にも亀裂 が現われた．その後 281 万回まで繰り返したのち試験を 終了した．試験後の亀裂の状況を Fig. 12 に示す．亀裂

（g）が最初に発見された亀裂で, 発見時 $22 \mathrm{~mm} の$ 表面 亀裂が最終的には $82 \mathrm{~mm}$ の貫通亀裂となっている. 亀 裂 $(\mathrm{h}) ，(\mathrm{i})$ は軌道析内側からみたもので亀裂 $(\mathrm{g})$ が 貫通したものである.この亀裂の破面をPhoto 2 に示す. 溶着金属の表面近くにブローホールの存在が認められ， そこから亀裂が発生している. 上記の亀裂のほかに，横 桁ウェブのスカラップ部に亀裂（f）が発見されたが, 大きな進展は認められなかった。

2 体目 (CP 2) では 281 万回の繰返し後も疲労亀裂 の発生は認められなかった。

$\mathrm{CP} 1$ で疲労亀裂が生じたのは溶接部にブローホール が存在したためであり，コーナープレート端部を滑らか にグラインダー仕上げした本構造は完全な溶接を施せば 改良された構造として有効であると考える.
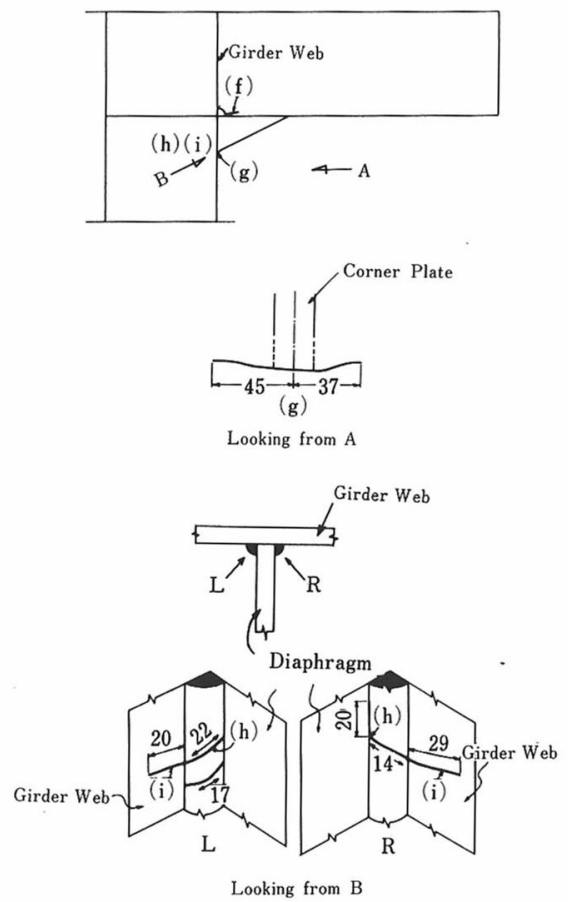

Fig. 12 Fatigue Cracks in Test Model with Corner Plate (CP 1).

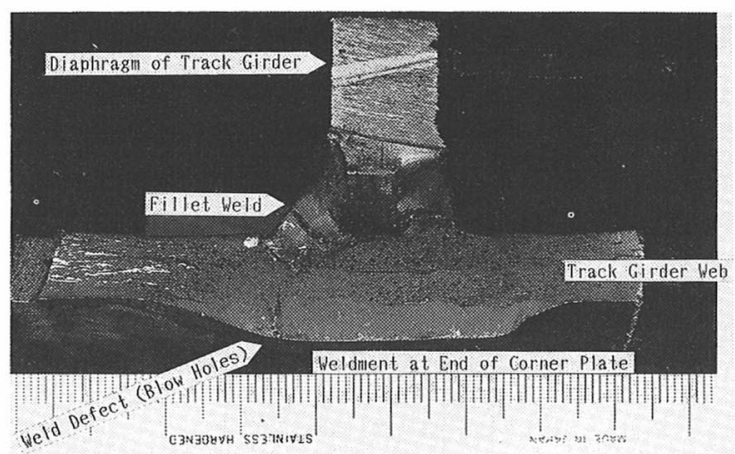

Photo2 Fracture Surface.

\section{5. テーパーを有する横桁連結部（TP）の疲 労試験}

試験体を 2 体製作した， 1 体目（TP 1) の形状を Fig. 11 に示す. 軌道桁内のリブプレートを一枚板とし, ダイアフラムを $2 つ に$ 分割した．さらに，2つに分割さ れたダイアフラムに生じるスカラップ，および横桁の ウェブのスカラップをすべて溶接で埋め戻した．横析を 両側に取り付け 1 つの試験体で左右 2 回の疲労試験を 行った．横桁は直線テーパーを有する変断面となってい る. 1 体目右側 (TP 1 R) の横桁連結部では, 軌道桁ウェ ブの手前 $100 \mathrm{~mm}$ の位置でテーパーが終り, 横析の上フ 
ランジは軌道桁のウェブと直交している．その他の横桁 連結部では軌道桁ウェブの位置までテーパーし，横析の 上フランジと軌道析のウェブとは斜めに交わっている. 左側と右側の横桁連結部をそれぞれ TP 1 L と TP 1 R または TP 2 L と TP $2 \mathrm{R}$ とよぶ. 1 体目 (TP 2 ) では, 軌道桁内のダイアフラムの孔は設けていない。一方 2 体 目左側 (TP 2 L) では, 実構造と同じように開孔した後, 添接板でこの孔を塞いで試験した. 続く右側の試験 (TP $2 \mathrm{R})$ ではこの添接板を外し，開孔の影響を調べた.

TP $1 \mathrm{~L}$ と TP $1 \mathrm{R}$ は $\pm 90.2 \mathrm{kN}$ の荷重下で試験した. 繰返し数 281 万回で両者とも疲労亀裂の発生は認められ なかった。本構造は横析連結部の改良構造として有効で あるといえる。

TP 1 R については荷重を $\pm 196 \mathrm{kN}$ に増加させて, 疲 労試験を続行した. 荷重増加後繰返し数 12 万回で, Fig. 13 に示すように, 横枌の上フランジを軌道析のウェ ブに連結する $\mathrm{K}$ 型 $\mathrm{T}$ 継手溶接の横桁フランジ側の溶接 止端に沿って長さ $40 \mathrm{~mm}$ の疲労亀裂（k）を発見した. 繰返し数 35.4 万回で疲労試験を終了した.

TP 2 L は土147 kN の荷重で疲労試験を行った。繰 返し数 90 万回で, Fig. 13 に示す横析の上フランジを軌 道桁のウェブに連結する $\mathrm{K}$ 型 $\mathrm{T}$ 継手溶接部の表面にで きたビードパス間の谷底に, 長さ $40 \mathrm{~mm}$ の疲労亀裂 $(\mathrm{j})$ を発見した。 その後繰返し数 110 万回で疲労試験を終了

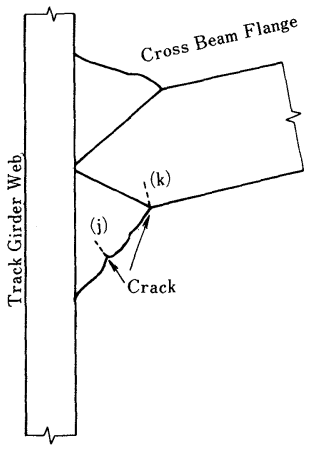

Fig. 13 Fatigue Cracks in Weldment to connect Track Girder Web to Top Flange of Cross Beam.

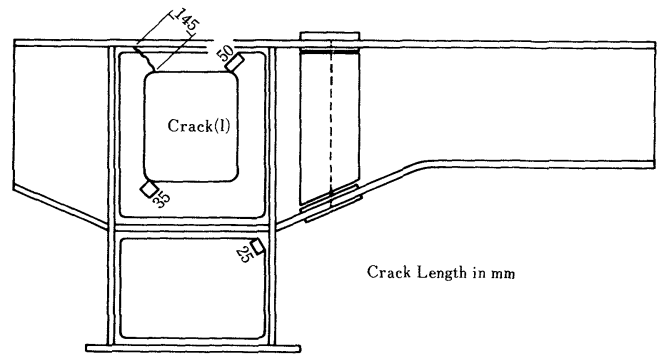

Fig. 14 Fatigue Cracks on Diaphragm of Test Model TP 2 R.
した.

TP $2 \mathrm{R}$ は $\pm 90.2 \mathrm{kN}$ の荷重の繰返しに対して 31 万回 で, TP $2 \mathrm{~L}$ と同じ疲労亀裂（j）を発見した．繰返し数 50 万回で軌道桁内のダイアフラムの孔のコーナー部に 疲労亀裂が生じ急速に生長し，75 万回で Fig. 14 に示す ように，ダイアフラムを横断する疲労亀裂となった。

\section{6. 結果の考察}

\section{（1）疲労亀裂発生点における局部ひずみ}

$\mathrm{CP}$ 構造の軌道桁ウェブとコーナープレートの溶接上 端部近傍で計測されたひずみの分布を Fig. 15 に示す. 図中の鎖線はコーナープレートの上端の形状を表わして いる. CP 1 と CP 2 ともにコーナープレートの上端で ひずみが最大値となっており, 疲労亀裂発生点と一致し ている．ここで得られた最大ひずみは，亀裂発生点にお ける真のひずみ值であり, 後述するホットスポットひず みとは定義が異なる。

$\mathrm{ST}$ 構造と TP 構造の軌道桁ウェブと横桁の上フラン ジの交差部近傍で計測されたひずみの分布を Fig. 16 に 示す. 本構造のように「構造上の不連続部をもつ溶接継 手部の疲労強度は，溶接部に生じる局部的なひずみ範囲 を縦軸とした $S-N$ 線図で整理することにより，構造型 式が異なる場合にも一本の $S-N$ 線図で表わすことがて きる」という考え方は海洋構造物の設計などでよく用い られている4).ところで，溶接止端におけるひずみは， 主として溶接ビードの形状・寸法に依存する局部的な応 力集中と板どうしの交差部などの構造の不連続による応 力集中の影響を受ける. しかし，溶接ビードの形状・寸 法に依存する局部的ひずみを求めることは難しく, 上述 の $S-N$ 線図の縦軸としては溶接ビードの形状に依存し ない構造的な応力集中のみを考慮したひずみがよく用い られ “ホットスポットひずみ”とよばれる。このホット

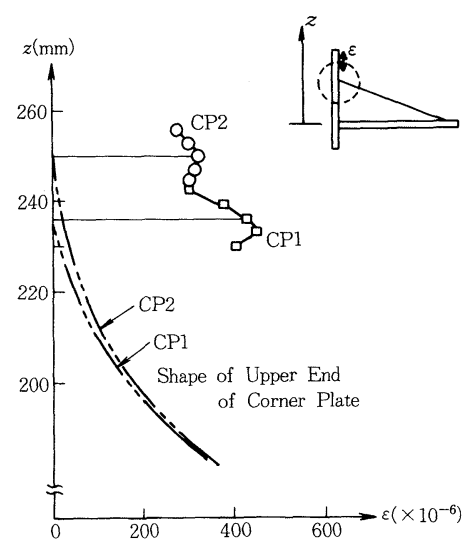

Fig. 15 Strain Distributions at Upper End of Corner Plate of Test Models $\mathrm{CP} 1$ and $\mathrm{CP} 2(P=90.2 \mathrm{kN})$. 

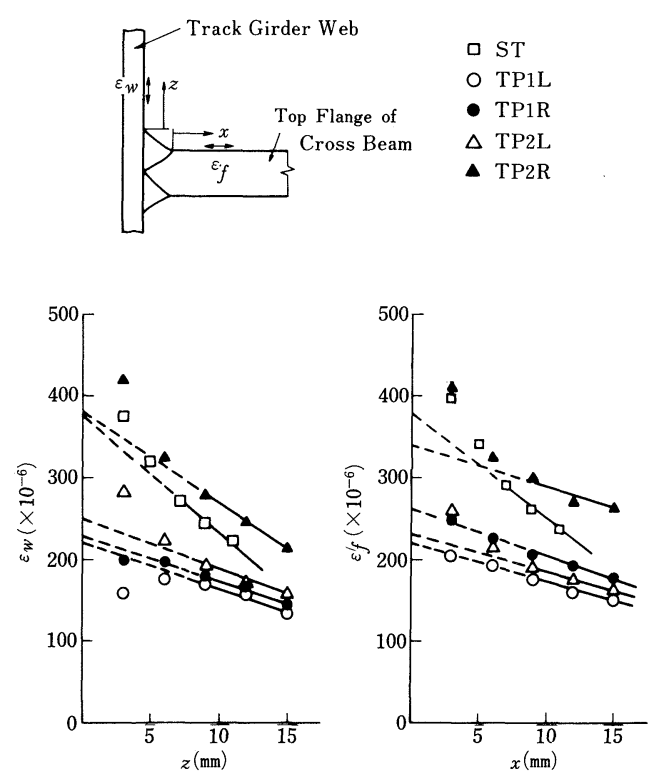

Fig. 16 Strain Distributions near Weldment to Connect Track Girder Web to Top Flange of Cross Beam (ST, TP 1, TP $2 ; P=90.2 \mathrm{kN}$ ).

スポットひずみは溶接ビードの影響を受けない範囲で計 測したひずみから止端におけるひずみを外挿により求め る必要がある．たとえば Gibstein ${ }^{5)}$ は止端より板厚の 1/4 か $4 \mathrm{~mm}$ の小さい方の距離の点から外挿している. また田村 ${ }^{6}$ は止端より板の $1 / 2$ と 1 倍離れた点から線形 外挿している. しかしまだ, その求め方は確立されてい ないのが現状である．本研究では溶接止端より $10 \mathrm{~mm}$ 程度離れた位置のひずみから直線外挿した溶接止端にお けるひずみをホットスポットひずみとして求めた。

\section{（2） $\boldsymbol{S}-\boldsymbol{N}$ 線図}

疲労試験結果を Table 2 に示す. $\Delta P$ は載荷荷重の 範囲である. $\Delta \sigma_{n}$ は, 棒理論から求められる, 軌道桁ウェ ブの位置における横桁のフランジ応力の範囲である. $\Delta \varepsilon$ はホットスポットひずみ範囲である. $N_{c}$ は疲労亀裂 が発見されたときの繰返し数であり， $N_{f}$ は疲労試験終 了時の繰返し数である.

$\mathrm{ST}$ 構造と TP 構造について, $\Delta P$ と $N_{c}$ の関係, $\Delta \sigma_{n}$ と $N_{c}$ の関係， $\Delta \varepsilon$ と $N_{c}$ の関係をそれぞれ Fig. 17, 18, 19 に示す. $\Delta P$ と $N_{c}$ の関係および $\Delta \sigma_{n}$ と $N_{c}$ の関係に おいては，ばらつきが大きく 1 つの $S-N$ 関係で表わす ことはできない。これに対して,$\Delta \varepsilon$ と $N_{c}$ の関係は比 較的小さいばらつきの範囲に収まっており，1つの $S-N$ 関係で表わすことができる．Fig.19中の実線は AWS-Code ${ }^{4)}$ で縦軸をホットスポットひずみ範囲とした ときに与えられている $X_{1}$ 線図である. 本実験結果はこ の $X_{1}$ 線図と同レベルに位置している.
Table2 Fatigue Test Results.

\begin{tabular}{|c|c|c|c|c|c|c|c|c|}
\hline $\begin{array}{l}\text { Mode I } \\
\text { No. }\end{array}$ & $\begin{array}{l}\text { load } \\
\text { Range } \\
\Delta \mathrm{P} \\
(\mathrm{KN})\end{array}$ & $\begin{array}{l}\text { Stress } \\
\text { Range } \\
\Delta \sigma_{\mathrm{n}} \\
(\mathrm{MPa})\end{array}$ & $\begin{array}{c}* 1 \text { T.F. } \\
\text { of C.B. } \\
\Delta \varepsilon \\
\left(\mathrm{X} 10^{-6}\right)\end{array}$ & $\begin{array}{c}* 2 \text { T.G } \\
\text { Web } \\
\Delta \varepsilon \\
\left(\times 10^{-6}\right)\end{array}$ & $\begin{array}{l}* 3 \\
\text { Crack } \\
\text { Types }\end{array}$ & $\begin{array}{c}* 4 \\
\mathrm{~N}_{c} \\
\left(\times 10^{4}\right)\end{array}$ & $\begin{array}{c}* 5 \\
N_{f} \\
\left(X 10^{4}\right)\end{array}$ & k \\
\hline ST & 294 & 94.8 & 1240 & 1225 & a & 0.57 & 21.9 & 4.22 \\
\hline CP1 & 180 & 56.8 & - & - & $\mathbf{g}$ & 230 & 281 & \\
\hline CP2 & 180 & 56.8 & - & - & no crack & $304 \nearrow$ & 304 & \\
\hline TP1L & 180 & 43.6 & 440 & 440 & no crack & $293 \nearrow$ & 293 & 2.44 \\
\hline TPYR & 180 & 43.6 & 520 & 450 & no crack & $281 \nearrow$ & 281 & 2.89 \\
\hline TP1R' & 392 & 96.8 & 1130 & 980 & $\mathrm{k}$ & 12.2 & 35.4 & 2.89 \\
\hline TP2L & 294 & 72.6 & 750 & 815 & j & 90 & 110 & 2.77 \\
\hline TP2R & 180 & 43.6 & 670 & 760 & $\mathbf{j}$ & 30.6 & 75 & 4.22 \\
\hline \multicolumn{9}{|c|}{$\begin{array}{l}\text { * } 1 \text { Local strain range on Top Flange of Cross Beam } \\
* 2 \text { Local strain range on Track Girder Veb } \\
* 3 \text { refer to Fig.9,Fig. } 12, F i g .13 \text { and Fig. } 14 \\
* 4 \text { Cycles when fatigue cracks were detected } \\
* 5 \text { Cycles when fatigue test terminated } \\
* 6 \mathrm{k}=\Delta \varepsilon / \Delta P\left[X 10^{-6} / \mathrm{MPa}\right]\end{array}$} \\
\hline
\end{tabular}

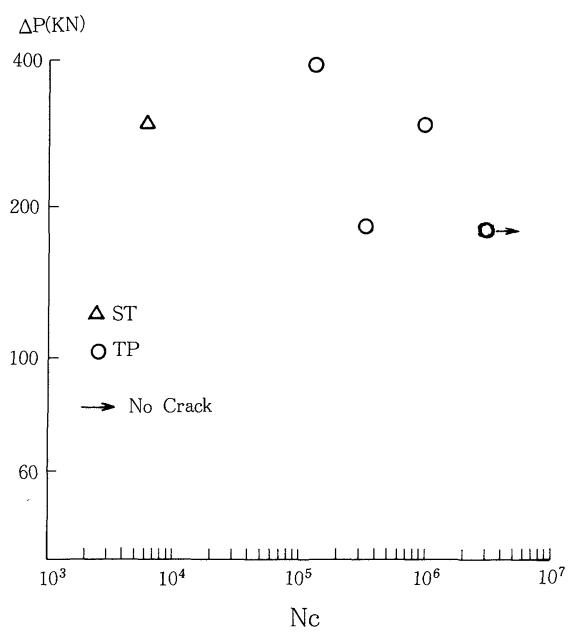

Fig. $17 \Delta P$ versus $N_{c}$.

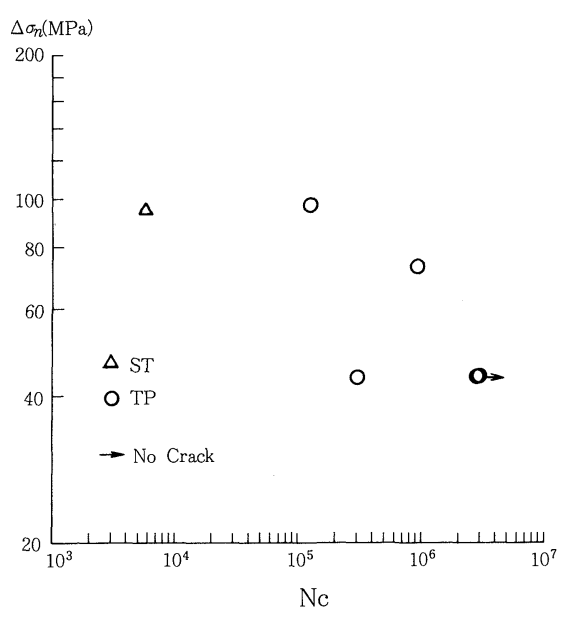

Fig. $18 \Delta \sigma_{n}$ versus $N_{c}$. 


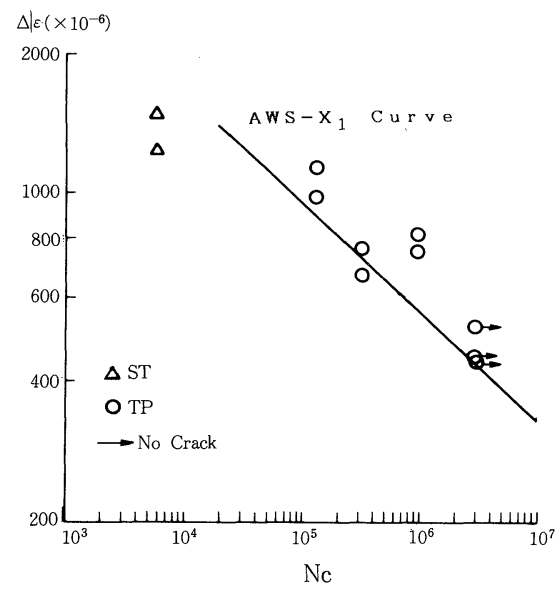

Fig. $19 \Delta \varepsilon$ versus $N_{c}$

\section{（3）横标連結部の構造改良の評価}

前述したように, 横析連結部の疲労強度は局部ひずみ の範囲 $\Delta \varepsilon$ を用いて統一的に表わされる. Table 2 中の $k$ は $\Delta \varepsilon$ と荷重範囲 $\Delta P$ の比で, 単位荷重下で生じる ホットスポットひずみ值を表わしている. $k$ の值が小さ くなるほど疲労強度が高いことになる. ST 構造の $k$ の 值は大きく,この構造は疲労亀裂の発生しやすい構造で ある. また，ダイアフラムの孔を開けたままの TP $2 \mathrm{R}$ の $k$ の值も大きく, ST 構造の $k$ の值に近い. したがっ て, TP 構造においては, ダイアフラムの孔は架設後添 接板で塞ぐことが疲労強度上必要である.

\section{7. 結 論}

跨座型モノレールの鋼製軌道析の横析連結部の疲労試 験を実施し，以下の成果を得た。

（1）棒理論から推定されるひずみをはるかに上回る 局部ひずみが軌道桁ウェブと横桁上フランジの交差部に 生じている.この局部ひずみ範囲を用いた,いわゆるホッ トスポットひずみの考え方に基づいて, 横桁連結部の疲 労強度を評価することが可能である.

（2）軌道桁内のリブプレートに存在するスカラップ から発生する疲労亀裂は, 横标の上フランジから軌道桁
に流れる力を遮断し，横桁連結部を破壊に導く．また， 横桁のウェブに存在するスカラップからも疲労亀裂が発 生する可能性がある．スカラップを溶接により埋め戻す ことにより，スカラップから発生する疲労亀裂を防止す ることができる.

（３） CP 構造では，コーナープレートの上端に生じ るひずみを小さくするため, 端部をグラインダーにより 仕上げ，端部の形状を滑らかに整える必要がある.

（4） ST 構造の改良構造として，TP 構造は優れて いる. しかし，軌道桁内のダイアフラムに製作上設けら れる孔を開けたままにしておくと，軌道桁ウェブと横桁 上フランジの交差部に生じる局部ひずみは増加する，さ らに, 孔の周辺に疲労亀裂が発生する可能性が高いので, 架設後, 添接板で塞がなければならない.

なお，実設計においては，CP 構造と TP 構造の両者 を採用した。

最後に，本研究の機会を与えていただき，研究の遂行 にあたりお世話になった，大阪府 小西一平氏，小笠原 洋一氏, および, 三井造船(株) 西川武夫氏, 沢柳政弘氏, 祝 賢治氏に厚く御礼申し上げます。

\section{参 考 文 献}

1）大阪府土木部：大阪モノレール構造物設計指針，pp.7〜 9, 1982

2）土木学会：国鉄建造物設計標準解説, pp. 174 176, 1983.

3) Zienkiewicz, O.C. and Cheung, Y.K. : The Finite Element Method in Structural and Continuum Mechanics, McGraw-Hill, pp. 66 67, pp. 90 98 and pp.124 . 137, 1967.

4) American Welding Society: ANSI/AWS D 1.1-81, Structural Welding Code Sec. 10 "Tubular Structures", 1981.

5) Gibstein, M. B. : Stress Concentration in Tubular Joints, It's Difinitions, Determination and Application, Conference Steel in Marine Structures, Paris, 1981.

6）田村英樹：溶接継手の構造的応力集中の解析に関する簡 易手法の提案, 日本溶接学会論文集,第 6 巻, 第 2 号, 1988 .

(1988.6.27·受付) 